\title{
Mycobacterium tuberculosis response to stress from reactive oxygen and nitrogen species
}

\section{Gyanu Lamichhane* \\ Center for Tuberculosis Research, Department of Medicine, Johns Hopkins University, Baltimore, MD, USA \\ ${ }^{*}$ Correspondence: lamichhane@jhu.edu}

\section{A commentary on}

The response of Mycobacterium tuberculosis to reactive oxygen and nitrogen species by Voskuil, M. I., Bartek, I. L., Visconti, K., and Schoolnik, G. K. (2011). Front. Microbiol. 2:105. doi: 10.3389/fmicb.2011.00105

The infectious life cycle of Mycobacterium tuberculosis $(M t b)$, as it relates to the disease tuberculosis (TB) in humans, begins from release of the bacilli in fine aerosol particles when an individual with active TB coughs or sneezes. When these bacilli are inhaled and reach the alveolar spaces of the lungs, they are ingested by phagocytic cells, primarily the macrophages. It is within the macrophages and also extracellularly during early and late stages of disease that $M t b$ has to thrive. The ability to survive is a prerequisite for $M t b$ to maintain infection without causing clinical disease, a condition known as "latent infection" that has allowed $M t b$ to maintain its reservoir in an estimated 2 billion humans (Jasmer et al., 2002). The ability to proliferate, both intracellularly and extracellularly is a prerequisite to cause active TB. Although majority of TB is pulmonary, $M t b$ can disseminate to and infect most organs and tissues causing a variety of $\mathrm{TB}$ diseases.

The host mounts a complex response to kill $M t b$ or limit its proliferation. Reactive oxygen and nitrogen intermediates have been widely reported and demonstrated as major antimicrobial molecules produced by the host (Nathan and Ehrt, 2004). Expression of nitric oxide synthase and markers associated with nitric oxide were observed to be expressed at elevated levels in the tuberculous lesion of lungs obtained from TB patients (Choi et al., 2002). Macrophages constitute a major host defense against $M t b$ infection; activated macrophages use nitric oxide against $M t b$ to kill or suppress its multiplication (Ehrt et al., 2001; Nathan and Ehrt, 2004). Macrophages obtained from bronchoalveolar lavages of TB patients and not from healthy individuals actively express nitric oxide synthase (Nicholson et al., 1996). Although the mouse model of TB does not fully recapitulate pathogenesis of TB and host response in humans, it has provided numerous lines of evidences suggesting a significant role of nitric oxide in limiting $M t b$ infection. Mice lacking nitric oxide synthase 2 are considerably more susceptible to $M t b$ infection than the parent wild-type strain (MacMicking et al., 1997). Activated macrophages that express nitric oxide synthase kill $M t b$ but this activity is lost in the presence of nitric oxide synthase inhibitors (Chan et al., 1992). The literature is less rich in its description of role of reactive oxygen species in TB. A transient attenuated response against $M t b$ infection in the absence of phox gene responsible for generating reactive oxygen species has been reported from a study that used mouse as the host (Cooper et al., 2000). However, the significance of reactive oxygen species in TB in humans and mechanism of action has yet to be confirmed. Two loci in the genome of $M t b$ have been recently identified and attributed to be involved in defense against host generated (Cirillo et al., 2009; Colangeli et al., 2009).

The molecular mechanism of action of nitric oxide is not fully understood although it has been shown to inhibit aerobic respiration in mitochondria as well (Brown, 2001). The Schoolnik laboratory has maintained a productive effort in understanding the effect of nitric oxide intermediates on $M t b$ and the pathogen's response to it. In 2003, Schnappinger and colleagues reported presence of physiologically significant oxidative and nitrosative stresses in macrophage phagosomes harboring $M t b$ (Schnappinger et al., 2003). Simultaneously, Voskuil et al. (2003) reported inhibition of respiration and growth of $M t b$ by nitric oxide. In addition, this study also identified a regulon comprising 48 genes that is modulated by nitric oxide. This regulon, now widely known as the " $M t b$ dormancy regulon" mediates physiological transition and adaptation to dormancy.

Voskuil et al. (2011) recently undertook an exhaustive study to profile whole genome expression in response to oxidative and nitrosative stresses. Hydrogen peroxide $\left(\mathrm{H}_{2} \mathrm{O}_{2}\right)$ and diethylenetriamine-nitric oxide adduct (DETA/NO) where used as donors of reactive oxygen and nitrogen intermediates respectively in an otherwise nutrient rich broth. Total RNA isolated from $M t b$ exposed to defined but a wide range of concentrations of $\mathrm{H}_{2} \mathrm{O}_{2}$ or $\mathrm{NO}$ donors were compared using oligonucleotide microarrays representing all genes of $M t b$. This is an exhaustive approach and yielded a more comprehensive list of stress-responsive genes than earlier studies. Expressions of a majority of the genes in the dormancy regulon were enhanced at low concentrations of NO (0.05 mM DETA/NO) but without affecting growth of $M t b$. At higher concentrations, numerous genes but with functions related to oxidative stress were also induced concurrently with the dormancy regulon.

The transcriptional response of $M t b$ to oxidative stress from $\mathrm{H}_{2} \mathrm{O}_{2}$, had similarities and differences compared to NO stress, revealing common and unique responses used by the bacteria against these stresses. The genes involved in DNA repair and recombination were selectively induced in the presence of $\mathrm{H}_{2} \mathrm{O}_{2}$. This suggests that DNA damage is a significant consequence following exposure to $\mathrm{H}_{2} \mathrm{O}_{2}$. Despite this significant insult on DNA, $M t b$ tolerated as high as $10 \mathrm{mM} \mathrm{H}_{2} \mathrm{O}_{2}$. Also induced by $\mathrm{H}_{2} \mathrm{O}_{2}$ exposure were several genes of $\mathrm{PE}$ and PPE family. Although this gene family makes up as much as $9 \%$ of the $M t b$ genome (Cole et al., 1998), their functions remain largely unknown.

Notably, this study revealed a common genetic apparatus used by $M t b$ to respond to oxidative and nitrosative stresses. Genes that encode functions related to general 
house-keeping and energy metabolism were repressed by both stresses. Genes involved in iron acquisition were also affected. These data are coherent with the hypothesis that insults from reactive oxygen and nitrogen intermediates are unfavorable to active metabolism and growth of $M t b$, and the bacteria alters expression of related genes to adapt accordingly. A large number of house-keeping and energy metabolism related genes were also reported to be affected in a similar way by Boshoff et al. (2004) who used a wide range of drugs, toxic compounds, and stresses known to affect metabolism and viability of $M t b$ to study changes to transcriptional profile of the bacteria.

Studies such as the one highlighted in this commentary that profile global expression generate a tremendous amount of data representing comprehensive response to condition being tested. Numerous genes identified by Voskuil and colleagues to be involved in oxidative and nitrosative stress response are annotated as having unknown functions. As these genes are characterized and functions encoded by them are defined, we stand to understand the molecular mechanism used by $M t b$ to adapt to stresses more clearly. Databases dedicated to genomics and annotation $^{1}$ and mining of transcriptional profiles $^{2}$ of $M t b$ can be expected to facilitate further understanding of these data.

\section{REFERENCES}

Boshoff, H. I., Myers, T. G., Copp, B. R., McNeil, M. R., Wilson, M. A., and Barry, C. E. III. (2004). The transcriptional responses of Mycobacterium tuberculosis

${ }^{1}$ http://tuberculist.epfl.ch/index.html

${ }^{2}$ http://www.tbdb.org/ to inhibitors of metabolism: novel insights into drug mechanisms of action. J. Biol. Chem. 279, 40174-40184.

Brown, G. C. (2001). Regulation of mitochondrial respiration by nitric oxide inhibition of cytochrome $\mathrm{c}$ oxidase. Biochim. Biophys. Acta 1504, 46-57.

Chan, J., Xing, Y., Magliozzo, R. S., and Bloom, B. R. (1992). Killing of virulent Mycobacterium tuberculosis by reactive nitrogen intermediates produced by activated murine macrophages. J. Exp. Med. 175, 1111-1122.

Choi, H. S., Rai, P. R., Chu, H. W., Cool, C., and Chan, E. D. (2002). Analysis of nitric oxide synthase and nitrotyrosine expression in human pulmonary tuberculosis. Am. J. Respir. Crit. Care Med. 166, 178-186.

Cirillo, S. L., Subbian, S., Chen, B., Weisbrod, T. R., Jacobs, W. R. Jr., and Cirillo, J. D. (2009). Protection of Mycobacterium tuberculosis from reactive oxygen species conferred by the mel 2 locus impacts persistence and dissemination. Infect. Immun. 77, 2557-2567.

Colangeli, R., Haq, A., Arcus, V.L., Summers, E., Magliozzo, R. S., McBride, A., Mitra, A. K., Radjainia, M., Khajo, A., Jacobs, W. R. Jr., Salgame, P., and Alland, D. (2009). The multifunctional histone-like protein Lsr2 protects mycobacteria against reactive oxygen intermediates. Proc. Natl. Acad. Sci. U.S.A. 106, 4414-4418.

Cole, S. T., Brosch, R., Parkhill, J., Garnier, T., Churcher, C. Harris, D., Gordon, S. V., Eiglmeier, K., Gas, S., Barry, C. E. III, Tekaia, F., Badcock, K., Basham, D., Brown, D., Chillingworth, T., Connor, R., Davies, R., Devlin, K., Feltwell, T., Gentles, S., Hamlin, N., Holroyd, S. Hornsby, T., Jagels, K., Krogh, A., McLean, J., Moule, S., Murphy, L., Oliver, K., Osborne, J., Quail, M. A., Rajandream, M. A., Rogers, J., Rutter, S., Seeger, K., Skelton, J., Squares, R., Squares, S., Sulston, J. E., Taylor, K., Whitehead, S., and Barrell, B. G. (1998). Deciphering the biology of Mycobacterium tuberculosis from the complete genome sequence. Nature 393, 537-544.

Cooper, A. M., Segal, B. H., Frank, A. A., Holland, S. M., and Orme, I.M. (2000). Transient loss of resistance to pulmonary tuberculosis in $\mathrm{p} 47$ (phox-/-) mice. Infect. Immun. 68, 1231-1234.

Ehrt, S., Schnappinger, D., Bekiranov, S., Drenkow, J., Shi, S., Gingeras, T. R., Gaasterland, T., Schoolnik, G., and Nathan, C. (2001). Reprogramming of the macrophage transcriptome in response to interferongamma and Mycobacterium tuberculosis: signaling roles of nitric oxide synthase- 2 and phagocyte oxidase. J. Exp. Med. 194, 1123-1140.

Jasmer, R. M., Nahid, P., and Hopewell, P. C. (2002). Clinical practice. Latent tuberculosis infection. $N$. Engl. J. Med. 347, 1860-1866.

MacMicking, J.D., North, R. J., LaCourse, R., Mudgett, J.S., Shah, S. K., and Nathan, C. F. (1997). Identification of nitric oxide synthase as a protective locus against tuberculosis. Proc. Natl. Acad. Sci. U.S.A. 94, 5243-5248.

Nathan, C., and Ehrt, S. (2004). "Nitric oxide in tuberculosis," in Tuberculosis, eds W. N. Rom and S. M. Garay (Philadelphia:LippincottWilliams \&Wilkins), 215-235.

Nicholson, S., Bonecini-Almeida Mda, G., Lapa e Silva, J. R., Nathan, C., Xie, Q. W., Mumford, R., Weidner, J. R., Calaycay, J., Geng, J., Boechat, N., Linhares, C., Rom, W., and Ho, J. L. (1996). Inducible nitric oxide synthase in pulmonary alveolar macrophages from patients with tuberculosis. J. Exp.Med. 183, 2293-2302.

Schnappinger, D., Ehrt, S., Voskuil, M. I., Liu, Y., Mangan, J. A., Monahan, I. M., Dolganov, G., Efron, B., Butcher, P. D., Nathan, C., and Schoolnik, G. K. (2003). Transcriptional adaptation of Mycobacterium tuberculosis within macrophages: insights into the phagosomal environment. J. Exp. Med. 198, 693-704.

Voskuil, M. I., Bartek, I. L., Visconti, K., and Schoolnik, G. K. (2011). The response of Mycobacterium tuberculosis to reactive oxygen and nitrogen species. Front. Microbiol. 2:105. doi: 10.3389/fmicb.2011.00105

Voskuil, M. I., Schnappinger, D., Visconti, K. C., Harrell, M.I., Dolganov, G. M., Sherman, D. R., and Schoolnik, G. K. (2003). Inhibition of respiration by nitric oxide induces a Mycobacterium tuberculosis dormancy program. J. Exp. Med. 198, 705-713.

Received: 23 July 2011; accepted:09August 2011; published online: 27 August 2011.

Citation: Lamichhane G (2011) Mycobacterium tuberculosis response to stress from reactive oxygen and nitrogen species. Front. Microbio. 2:176. doi: 10.3389/fmicb.2011.00176 This article was submitted to Frontiers in Cellular and Infection Microbiology, a specialty of Frontiers in Microbiology.

Copyright $\odot 2011$ Lamichhane. This is an open-access article subject to a non-exclusive license between the authors and Frontiers Media SA, which permits use, distribution and reproduction in other forums, provided the original authors and source are credited and other Frontiers conditions are complied with. 